\title{
The implementation of zoning system in suburban schools in Tulungagung Regency, Indonesia
}

\author{
Ariek Tri Ariani \\ SMP Negeri 2 Campurdarat. \\ J1. Trenggo No. 34, Campurdarat, Tulungagung, Jawa Timur 66272, Indonesia. \\ ariektriariani01@gmail.com \\ * Corresponding Author
}

\section{ARTICLE INFO}

\section{Article History}

Received:

26 February 2020;

Revised:

10 May 2020;

Accepted:

5 January 2021

\section{Keywords}

Implementation; Peripheral areas; Zoning

\begin{abstract}
This research aims to find out the meaning or nature; process; and the causal relationship between the school zoning system in the suburbs of Tulungagung Regency. This thesis was made using a qualitative descriptive approach with a multiple case study approach; to then associate research findings with several practical and empirical theories. These research objects are SMPN 2 Campurdarat, SMPN 1 Tanggunggunung, and SMPN 1 Besuki Tulungagung. The qualitative analysis technique used was the multiple case study, with the research instrument interviewing with school principals and acceptance of new students (PPDB) operators. This research was prepared based on several studies of the problem that the periphery school is one of the parties who benefit from implementing this zoning system compared to urban schools in Tulungagung Regency in terms of the ceiling's fulfillment. The findings of the study show that determination of the amount of ceiling in PPDB with the zoning system in schools in rural areas is following the regulations regarding the tensile strength of PPDB in Tulungagung Regency as stipulated in the Decree of the Head of the Youngest and Sports Education Office in Tulungagung Regency, Indonesia number: 188/1035/104.010/2019 concerning determination of schedule and capability of acceptance of new, kindergarten, elementary and middle school students in 2019/2020 academic year. The preparation of high human resources has well supported the process. The series of PPDB activities with the zoning system in rural areas in Tulungagung Regency has been carried out well by PPDB committees in each school. Evaluation of the implementation of PPDB with the zoning system in the outskirts of Tulungagung Regency has fulfilled aspects of effectiveness, efficiency, adequacy, equity, and responsiveness and accuracy; and an evaluation system has been carried out based on the principle of policy impact; i.e., comparing conditions before and after the policy is carried out.
\end{abstract}

This is an open access article under the CC-BY-SA license.

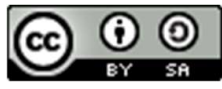

\section{INTRODUCTION}

The education system in modern society should fulfill two absolute functions: first, to equip individuals with the knowledge to participate in social, economic, and political life. Second, providing the broadest possible access to education as an effort to equalize the quality of education (Coleman, 1968 in Aditomo \& Felicia, 2018). Based on this theory, it is clear that the government has a role and function in providing the broadest possible access to the community to get a consistent education quality. One form of the implementation of the government's role is manifested in the form of a zoning system policy for the admission of new students in schools. According to Purwanti, 
Irawati, Adiwisastra, and Bekti (2019), new student admission or PPDB is the admission of students for kindergarten, elementary school, and junior high school, which is held at the beginning of the new academic year; where PPDB for junior high school level is carried out online with priority being children aged 12-15 years (Regulation of the Ministry of Education and Culture of the Republic of Indonesia, No. 17 of 2017). In its implementation since the 2017/2018 school year, junior high schools in the Tulungagung Regency area have implemented a zoning system, namely a system for admitting new students based on radius and distance, although not yet one hundred percent.

Some time past often appears complaints about the zone system in the recruitment of new students. Complaints arise from the school and prospective students and parents, as happened at the first secondary school level. Learners who want schools in educational institutions of their choice be realized due to the zoning system's policy. A recruitment zoning system allows new problems because the value of national test result is not used in the new school entrance, high or low value just the same origin with a radius house near the school, the value of the test results apply to track achievements but probably only $20 \%$, so there is a paradigm of the students and parents that do not need to study seriously because test scores are not used in entering a new school level. In addition to these problems, there are also problems that the school would be reluctant to innovate to compete with another school because the presence of this zoning system of the schools will be easy to get the students without having to do marketing or innovation because the program is definitely going to get a new learner. The school's zoning systems will be easy to get the students without having to do marketing or innovation because the program will get a learner. Innovation is more than just a change. Despite all of the innovations involving changes based on the theory, there will be no changes at the school (Ismabela, 2019).

The conflict that occurred was that many people supported and rejected the zoning system. People who support the PPDB zoning system think that it is related to distance, but mediocre children's achievement problems have the same opportunities as other high achieving students. It contradicts the assumption of high reaching parents who cannot send their children to state junior high schools, which have been considered favorites by the community. This contradiction of opinion can be illustrated that with the zoning system's implementation, students who have high rankings in schools are not necessarily acceptable in favorite schools. Vice versa, students whose schools are not ranked can enter into famous schools. Zoning problems are closely related to the readiness of teachers in the zoning system itself. Teachers must strive to educate various input students from their school zone optimally; with even output quality, they don't care about students whose input is fine. Based on this, we're worried about the first were students with useful input; however, it has mediocre output. The problems of both students with lousy information can affect the student's learning environment.

Another problem is that the number of schools in the Tulungagung Regency deems uneven per district, including each school's quality. This phenomenon was thought to be a boomerang for the zoning system regulations; in other words, the desire to equalize education quality. However, the quantity and quality of schools are relatively uneven in each region. According to Chinapah, Cars, and Grinberg (2013), the government has a role in the equality of the quality of education. According to Borowska-Beszta and Urban (2014), education quality can be improved with proper and systematic management. According to Sari and Setiawan (2018), management improvement can be made by utilizing information technology. According to Musa (2019), technology can help analyze management success.

Many problems are faced in the implementation of education. The problem is the cause of hampering the achievement of educational goals. Problems in education can be viewed from various aspects because education should cover many aspects. The results of on-the-spot monitoring on the ground are aspects of teachers, curriculum, learners, management, parents, government, environment, and society, facilities and infrastructure, National Exam implementation, and teacher teaching hours. According to Lufri and Yogica (2019), many problems are faced in the implementation of education. The problem is the cause of hampering the achievement of educational goals. Problems in education can be viewed from various aspects because education should cover many aspects. From the results of on-the-spot monitoring on the ground are aspects of teachers, curriculum, learners, management, parents, government, environment and society, facilities and infrastructure, National Exam implementation, and teacher teaching hours. 
Each section is introduced more specifically to help the reader see the relevance of each contribution. To summarize, the education profession is slowly but surely shifting away from exclusive interest in local experience for solutions to local problems to looking at the problems and solutions to similar issues in other parts of the world. Just as in public health, engineering, law, and business, global issues are not the only issues. However, they are important today and, therefore, are important for all educators to understand better (Heyneman, 2001). According to Singh and Shakir (2019), the problem can be solved through the teachers' role.

In addition to finding problems in the school zoning system, it turns out that the course considers being beneficial from the periphery schools. This is based on findings in schools outside the Tulungagung area, namely in the Surabaya area, which states that SMAN 22 Surabaya is one of the outskirt schools that indirectly benefit greatly from implementing the PPDB zone system (Widayanti \& Rosdiana, 2018). This statement was supported by the news in Detik News, which stated that the Tulungagung Youth and Sports Education Agency (Dinas Pendidikan, Pemuda dan Olahraga Republik Indonesia), Mr. Suharno, said that the zoning system registration would be carried out for three days from 19-21 June 2019 online if this zoning system prioritizes the distance between the house and the school; and optimistic that with the new system there will be an equal distribution of the number and value of each of the 48 new students in public schools spread across 19 districts. There will be no more students with good grades in one school, primarily at SMPN 1, 2, and 3 Tulungagung.

In addition to school readiness problems and the school's human resources, zoning problems also occur in the program system, especially at the location coordinates. An error in writing the coordinate point that befell hundreds of prospective new students at several state junior high schools in Tulungagung forcing the school to temporarily stop the entry process for the 2019 new student admissions zoning system (PPDB); there is a student from Punjul Village, Karangrejo District with the address of his home village and the school which should not be more than two kilometers. However, due to the incorrect writing of the azimuth data or coordinate points of this student, it seemed as if they were registered outside the zoning of SMPN 3 Tulungagung (Bakrie and Pamungkas, 2019). Based on the various problems above, the research aims to determine the meaning or nature of school zoning system planning at SMPN in the suburbs of Tulungagung Regency; knowing the school zoning system process at SMPN in the suburbs of Tulungagung Regency, and knowing the causal relationship of the school zoning system at SMPN in the suburbs of Tulungagung Regency.

\section{METHOD}

Research methods for this study are used a qualitative approach to approach the problem's focus under investigation with the nature of the problem-solving flow according to various theoretical studies, to then compare the results with conditions in the field. This research approach uses a case study. This research's location is at SMPN 2 Campurdarat, SMPN 1 Tanggunggunung, and SMPN 1 Besuki. The reason for choosing this location base on preliminary observations that the school had implemented a zoning-based PPDB relatively well compared to other schools in the same area. Also, the school is more than 12 kilometers from the urban center of Tulungagung Regency. The data collection procedure is carried out by passive observation. It unstructured interviews where subjects know that they are being interviewed. The interview process follows the flow of the PPDB-based zoning activity process, documentation of several related regulations, technical instructions (implementation modules) imposed by each school in implementing zoning-based PPDB, student registration forms, and other documents that can support the validity of research data findings, such as the results of the implementation process documentation. The qualitative analysis process used is by examining the class's phenomena, which is the object of research. And then projected on standard practical and empirical theories, which are then interpreted (interpreted) based on the theories used in this research, one of which is the Van Meter and Van Horn policy theory. This research is a case study with three objects under review. It then analyzes through the multiple case study analysis model, case Quaintance dialectic using a two-step analysis, namely case analysis, and cross-case analysis. 


\section{FINDINGS AND DISCCUSIONS}

PPDB Based on the Zoning System for SMPN in the Tulungagung Region

Based on the results of observations and interviews, it was found that the implementation of PPDB with the zoning system in schools in the suburbs of Tulungagung Regency had been carried out well, including in terms of planning, organizing, and evaluating. PPDB can do using the Van Meter and Van Horn implementation model approach (Lestari \& Rosdiana, 2018; Rolenta, 2018). The results of this study are following the implementation of the zoning-based PPDB in the suburbs of the Regency, which in general meets the aspects according to the size and policy objectives; resource; implementing agent characteristics; attitudes/tendencies (dispositions) of the implementers; communication between implementing activity organizations; and the economic, social and political environment. Various reasons implemented PPDB Zoning System Based in the Outskirt of Tulungagung Regency.

Some things that are considered necessary from the implementation of the zoning system in the periphery areas are: For schools, the fulfillment of the student ceiling/quota, there is a high possibility of obtaining high-quality student input, simplifying the registration process, providing opportunities for suburban schools to become favorite junior high schools in their regions with the hope that one day they will be able to compete with favorite SMPNs in the city area. It is relevant to research which states that schools in one zone with low resource quality while in another location favorite schools gather so that zoning can move the gap from the school level to the zone level (Aditomo \& Felicia, 2018b). Parents do not need to bother taking their children too much (tend to issue the usual cheap transportation). Parents are not too anxious about choosing a school (because the choices are limited). Parents have wider opportunities to coordinate with teachers. It is relevant to research that states that this zoning school can positively impact the guardians of students who want to send their children to favorite schools but at an affordable cost (Hanifah \& Wahyudi, 2019). For students, the risk of student delay will below. The teacher's emotional bond is tighter because the teacher will also get to know the parents more closely. High achieving students will be able to freely do exercises in school and speed up handling time in students' problems. Students will pay more attention to the teacher due to the teacher quickly finding information about students' condition both from peers and from other environments close to the student's domicile (Hanifah \& Wahyudi, 2019).

Implementation of PPDB in Tulungagung Regency

The determination of the ceiling amount on the zoning-based PPDB implementation is following the regulations regarding the capacity as stated in the Decree of the Head of the Education, Youth and Sports Office of Tulungagung Regency (Dinas Pendidikan Pemuda dan Olahraga Kabupaten Tulungagung) Number: 188/1035/104.010/2019 concerning determining the schedule and capacity for the admission of new students (PPDB) kindergarten, elementary, and junior high school year 2019/2020. Whereas in the planning process it is following the Regulation of the Regent of Tulungagung No. 20 of 2019 concerning technical guidelines and the determination of zoning for new student admissions at kindergartens, elementary schools, and junior high schools in Tulungagung Regency states that the school's duties as PPDB organizers are related to planning to the zone is determining the capacity of each school following the existing facilities, prepare administration for the implementation of registration, and disseminating information to the public about the implementation of PPDB (Regent of Tulungagung, 2019). Through the education office, the central government has provided training in technical guidance to school principals and PPDB operators prepared by the school. This process has been carried out well in each school. The findings above are relevant to the theory, which states that the school has provided the facilities and facilities needed to implement PPDB, such as computers and admin staff, to assist prospective students in registering for school (Lestari \& Rosdiana, 2018).

Implementation of PPDB with a Zoning System

The series of PPDB implementation activities with a zoning system in junior high schools in the suburbs of Tulungagung Regency has been carried out well by PPDB committees in each 
school and following the regulation of the regent of Tulungagung Number 20 of 2019 concerning technical instructions and determination of zoning for new student admissions at kindergartens, elementary schools, and junior high schools in Tulungagung Regency. In terms of coordination and communication from each PPDB committee, it is found that what the school has done is relevant to research which states that the better the coordination of communication between the parties involved in an implementation process, then the assumption is that errors will be very small to occur and vice versa (Lestari \& Rosdiana, 2018; Rolenta, 2018).

Evaluation of PPDB Implementation with a Zoning

The effectiveness of a system's facilities and infrastructure occurs if all work together and provide mutual support. Like what happened to PPDB in suburban schools in the Tulungagung Regency area, all education components work together to maximize PPDB facilities and infrastructure. As a result, PPDB activities in each school experienced things that were more effective than before. It is relevant to the theory, which states that the school has provided the facilities and facilities needed to implement PPDB, such as computers and admin staff, to help prospective students register for school (Lestari \& Rosdiana, 2018). The quality of system services in suburban schools has fulfilled an excellent aspect of managing the PPDB program based on this zoning system; however, there are still frequent problems related to coordinate points. People become restless and feel that the service is not optimal. The quality of service that has not been maximally related to this coordinate point contradicts Albrecht and Zemke in Rolenta (2018), which states that educational programs in an educational policy must pay attention to the quality of the program. The education program is an academic service to the community. The process of evaluating the implementation of PPDB with a zoning system in the suburbs in the Tulungagung Regency has fulfilled the evaluation aspects which can be analyzed using the theory of William N. Dunn regarding policy evaluation, namely effectiveness, efficiency, adequacy, equity, and responsiveness and accuracy (Widayanti \& Rosdiana, 2018). The evaluation system is also relevant to research, which states that evaluating the impact of policies is carried out by comparing conditions before and after the procedure is implemented (Prasetyo, 2018).

The admission student zoning system has changed the paradigm of education in Indonesia, such as eliminating favorite and not favorite schools and making all schools a favorite. This purpose is not easy if not followed with increasing the existing education quality standards. The zoning system has fundamentally changed by "student interest," which is the main problem. The admission student zoning system offers more convenience and "local diversity." Comfort in the sense of a school that is close to home while increasing the sense of ownership. Local diversity means that students must be able to accept the conditions in their area of adjustment, not only students, as well as schools and their supporting factors while at the same time increasing the quality at least towards the minimum standard of education services (Bakar, Supriyati, \& Hanafi, 2019).

The zoning system acceptance criteria of learners based on the proximity of the school and residence learners. Zoning system policy practices reap the pros and cons of the community. However, the zoning system meant that no superior schools. Superior levels of income and learners homogeneous. Policies intended the zoning system so that learners can school near the villages. Concerning learning, favorite school zoning system change (formerly known as the cluster system) to be evenly distributed. The zoning system is not the subject of discussion is complicated. This is because through the zoning system where learners are much more transparent. Social capital in perspective, social learning is applied to the zoning system and is expected to bridge various social issues. Therefore, social issues and education can serve as a strategic issue to establish national awareness (Mutiani \& Subiyakto, 2019).

\section{CONCLUSION}

The conclusion of this study is to evaluating of the implementation of PPDB with the zoning system in the outskirts of Tulungagung Regency has fulfilled aspects of effectiveness, efficiency, adequacy, equity, and responsiveness, and accuracy, and an evaluation system has been carried out 
based on the principle of policy impact. The polemic regarding PPDB with the zoning system in the community is still a polemic to this day. Thus, the researcher proposes that the school continue to socialize more incentives about the extraordinary impact of implementing this system on the community. There are still many high-achieving students going to suburban schools. It is suggested that the school improve the quality of learning even higher, both academically and non academically. Because PPDB with the zoning system brings closer the distance between the house and the school, it is suggested that the school motivate the teacher to build a high emotional attachment to parents because the role of the surrounding environment towards students who are on average towards the adult level is relatively able to influence their learning patterns.

Research recommends that the managed servers often experience downtime (difficult to access due to too many users) based on the findings presented. It is advisable to improve the quality of the servers provided so that such things do not happen. This is quite reasonable because the school directly serves the community, while the community (parents) may not understand the server down problem. There are many errors in the placement of azimuth points; Therefore, it is suggested to provide socialization and easy-to-understand guidance in determining the azimuth point. There are still many polemics that occur in the community regarding the zoning-based PPDB. People always disseminate information about the uses and benefits of the zoning-based PPDB policy to understand. Make the child/daughter aware; to realize that the essence of any school is the same thing. It only depends on the learner whether to be serious or not. 8. Based on the findings, it is found that there are many schools in rural areas that are likely to receive input from high-achieving students. For this reason, it is suggested in further research to examine various appropriate learning models for suburban schools related to the PPDB phenomenon. This research is only focused on SMPN schools in rural areas. So further research is needed to compare the PPDB phenomenon in urban and suburban areas.

\section{REFERENCES}

Aditomo, A., \& Faridz, N. F. (2019). Ketimpangan mutu dan akses pendidikan di Indonesia: Potret berdasarkan survei PISA 2015. Kilas Pendidikan, 17, 1-8. Retrieved from https://osf.io/preprints/inarxiv/k76g3/download

Bakar, K. A. A., Supriyati, Y., \& Hanafi, I. (2019). The evaluation of admission student policy based on zoning system for acceleration education quality in Indonesia. Journal of Management Info, 6(2), 19-24. doi: https://doi.org/10.31580/jmi.v6i2.883

Bakrie, N. \& Pamungkas, B. (2019, July 14). Entri sistem zonasi PPDB 2019 SMP di Tulungagung dihentikan sementara. JatimNow. Retrieved from https://jatimnow.com/baca-17177-entrisistem-zonasi-ppdb-2019-smp-di-tulungagung-dihentikan-sementara.

Borowska-Beszta, B., \& Urban, R. (2014). A case study of cognitive-educational support for elderly female with Alzheimer's disease. International Research Journal for Quality in Education, 1(6), 7-17. Retrieved from https://nbn-resolving.org/urn:nbn:de:0168-ssoar-409284

Chinapah, V., Cars, M., \& Grinberg, S. (2013). Global efforts towards quality education for all: Evidence and reflections from an international and comparative educational perspective. Journal of Education and Research, 3(2), 39-58. doi: https://doi.org/10.3126/jer.v3i2.8397

Hanifah, L. N., \& Wahyudi, T. N. (2019, April). Peranan sekolah kawasan berbasis sistem zonasi sekolah dalam pembentukan karakter siswa di era milenial (Studi kasus di SMA Negeri 2 Wonogiri). Paper presented at Seminar Nasional Pendidikan 2019, Universitas Negeri Semarang, Indonesia. Retrieved from http://hdl.handle.net/11617/10762.

Heyneman, S. P. (2001). General introduction: Global issues in education. Peabody Journal of Education, 76(3-4), 1-6. doi: https://doi.org/10.1080/0161956X.2001.9681987

Ismabela, J. (2019, December). The Impact of Zoning System to Student Achievement and School Innovation. In 3rd International Conference on Education Innovation (ICEI 2019) (pp. 292294). Atlantis Press. doi: https://doi.org/10.2991/icei-19.2019.68

Volume 7, No. 2, September 2020 
Lestari, H. A., \& Rosdiana, W. (2018). Implementasi kebijakan Penerimaan Peserta Didik Baru (PPDB) di SMA Negeri 4 Kota Madiun Tahun 2017. PUBLIKA, 6(5), 1-7. Retrieved from https://jurnalmahasiswa.unesa.ac.id/index.php/publika/article/view/23237/21244

Lufri, L., \& Yogica, R. (2019). Profile of science education problems in west sumatera and its surroundings. Journal of Physics: Conference Series, 1317(1), 012186. doi: https://doi.org/0.1088/1742-6596/1317/1/012186

Musa, M. (2019). An analysis of quality assurance key performance indicators in research in Ugandan Universities. International Journal of Instruction, 12(1), 1567-1584. doi: https://doi.org/10.29333/iji.2019.121100a

Mutiani, M., \& Subiyakto, B. (2019). Social capital in social studies through zoning school system. International Journal Pedagogy of Social Studies, 4(2), 95-100. doi: https://doi.org/10.17509/ijposs.v4i2.21491

Muttaqin, A. (2019, July 14). Kadisdik Tulungagung: PPDB zonasi untungkan sekolah pinggiran. detiknews. Retrieved from https://news.detik.com/berita-jawa-timur/d-4591023/kadisdiktulungagung-ppdb-zonasi-untungkan-sekolah-pinggiran.

Prasetyo, J. (2018). Evaluasi dampak kebijakan sistem onasi PPDB terhadap jarak tempat tinggal dan biaya transportasi pelajar SMA di DIY (Unpublished doctoral dissertation). Universitas Gadjah Mada, Indonesia.

Purwanti, D., Irawati, I., Adiwisastra, J., \& Bekti, H. (2019). Implementasi kebijakan penerimaan peserta didik baru berdasarkan sistem zonasi di kota Bandung. Jurnal Governansi, 5(1), 12 23. doi: http://dx.doi.org/10.30997/jgs.v5i1.1699

Rolenta, A. R. (2018). Implementasi kebijakan Penerimaan Peserta Didik Baru (PPDB) online tingkat sekolah menengah atas di Dinas Pendidikan Provinsi Sumatera Utara (Unpublished bachelor's dissertation). Universitas Sumatra Utara, Indonesia. Retrieved from http://repositori.usu.ac.id/handle/123456789/3360.

Sari, A., \& Setiawan, A. (2018). The development of internet-based economic learning media using moodle approach. International Journal of Active Learning, 3(2), 100-109. Retrieved from https://www.learntechlib.org/p/208671/.

Singh, L., \& Shakir, M. (2019). Teacher education: Issues and concerns in current scenario. International Journal of Research and Analytical Reviews (IJRAR), 6(2), 1082-1091. Retrieved from https://www.researchgate.net/publication/333193852_Teacher_Education _Issues and Concerns in Current_Scenario

Widayanti, D., \& Rosdiana, W. (2019). Evaluasi Kebijakan Penerimaan Peserta Didik Baru di SMAN 22 Surabaya tahun 2018. PUBLIKA, 7(4), 34-42. Retrieved from https://jurnalmahasiswa.unesa.ac.id/index.php/publika/article/view/27380/25048 